\title{
Early Changes in KCC2 Phosphorylation in Response to Neuronal Stress Result in Functional Downregulation
}

\author{
Hiroaki Wake, ${ }^{1,2}$ Miho Watanabe, ${ }^{1}$ Andrew J. Moorhouse, ${ }^{3}$ Takashi Kanematsu, ${ }^{4}$ Shoko Horibe, $, 1,6$ \\ Noriyuki Matsukawa, ${ }^{2}$ Kiyofumi Asai, ${ }^{5}$ Kosei Ojika, ${ }^{2}$ Masato Hirata, ${ }^{4}$ and Junichi Nabekura ${ }^{1,6,7}$ \\ ${ }^{1}$ Division of Homeostatic Development, National Institute of Physiological Sciences, Okazaki 444-8585, Japan, ${ }^{2}$ Department of Neurology and Neuroscience, \\ Nagoya City University Graduate School of Medical Sciences, Mizuho-ku, Nagoya 467-8601, Japan, ${ }^{3}$ Department of Physiology and Pharmacology, School of \\ Medical Sciences, University of New South Wales, Sydney, New South Wales 2052, Australia, ${ }^{4}$ Molecular and Cellular Biochemistry, Faculty of Dental \\ Science, Kyushu University, Fukuoka 812-8582, Japan, ${ }^{5}$ Department of Molecular Neurobiology, Nagoya City University Graduate School of Medical \\ Sciences, Nagoya 467-8601, Japan, ${ }^{6}$ School of Life Science, The Graduate University for Advanced Studies, Hayama 240-0193, Japan, and ${ }^{7}$ Core Research for \\ the Evolutionary Science and Technology, Japan Science and Technology Corporation, Saitama 332-0012, Japan
}

The $\mathrm{K}^{+} \mathrm{Cl}^{-}$cotransporter KCC2 plays an important role in chloride homeostasis and in neuronal responses mediated by ionotropic GABA and glycine receptors. The expression levels of KCC2 in neurons determine whether neurotransmitter responses are inhibitory or excitatory. KCC2 expression is decreased in developing neurons, as well as in response to various models of neuronal injury and epilepsy. We investigated whether there is also direct modulation of KCC2 activity by changes in phosphorylation during such neuronal stressors. We examined tyrosine phosphorylation of KCC2 in rat hippocampal neurons under different conditions of in vitro neuronal stress and the functional consequences of changes in tyrosine phosphorylation. Oxidative stress $\left(\mathrm{H}_{2} \mathrm{O}_{2}\right)$ and the induction of seizure activity (BDNF) and hyperexcitability $\left(0 \mathrm{Mg}^{2+}\right)$ resulted in a rapid dephosphorylation of KCC2 that preceded the decreases in KCC2 protein or mRNA expression. Dephosphorylation of KCC2 is correlated with a reduction of transport activity and a decrease in $\left[\mathrm{Cl}^{-}\right]_{\mathrm{i}}$, as well as a reduction in KCC2 surface expression. Manipulation of KCC2 tyrosine phosphorylation resulted in altered neuronal viability in response to in vitro oxidative stress. During continued neuronal stress, a second phase of functional KCC2 downregulation occurs that corresponds to decreases in KCC2 protein expression levels. We propose that neuronal stress induces a rapid loss of tyrosine phosphorylation of KCC2 that results in translocation of the protein and functional loss of transport activity. Additional understanding of the mechanisms involved may provide means for manipulating the extent of irreversible injury resulting from different neuronal stressors.

Key words: $\mathrm{KCC} 2$; neurons; $\mathrm{E}_{\mathrm{Cl}^{-}} ; \mathrm{Cl}^{-}$homeostasis; oxidative stress; cell death

\section{Introduction}

The $\mathrm{K}^{+} \mathrm{Cl}^{-}$cotransporter, $\mathrm{KCC} 2$, plays an important role in neuronal $\mathrm{Cl}^{-}$homeostasis and in determining the physiological response to the activation of anion-selective GABA and glycine receptors (for review, see Kaila, 1994; Delpire, 2000; Payne et al., 2003). Increases in the expression level of KCC2 underlie the developmental change in GABA and glycine responses from depolarization to hyperpolarization, and different neuronal expression levels correlates with differences in GABA responses and the ability to maintain $\mathrm{Cl}^{-}$homeostasis during depolarization (Kakazu et al., 1999; Rivera et al., 1999; Ueno et al., 2002; Zhu et al., 2005). Conversely, KCC2 expression levels are reduced in various pathological conditions, including axotomy and nerve crush, nerve cuff-induced chronic pain, and interictal activity,

\footnotetext{
Received Feb. 27, 2006; revised Jan. 4, 2007; accepted Jan. 5, 2007.

This work was supported by Grants-in-Aid for Scientific Research (5023783) from the Ministry of Education, Culture, Sports, Sciences, and Technology, Japan and by the Japan Science and Technology Agency (J.N.).

Correspondence should be addressed to Dr. Junichi Nabekura, Division of Homeostatic Development, Department of Developmental Physiology, National Institute of Physiological Sciences, Okazaki 44-8585, Japan. E-mail: nabekura@nips.ac.jp.

D0I:10.1523/JNEUROSCI.3104-06.2007

Copyright $\odot 2007$ Society for Neuroscience $\quad$ 0270-6474/07/271642-09\$15.00/0
}

with a resultant increased $\left[\mathrm{Cl}^{-}\right]_{\mathrm{i}}$ and a shift of GABA-mediated responses from hyperpolarizing to depolarizing (Nabekura et al., 2002; Rivera et al., 2002, 2004; Coull et al., 2003; Toyoda et al., 2003). The changes in neuronal $\mathrm{Cl}^{-}$homeostasis in these pathological conditions resemble a temporary return to an immature phenotype, speculated to be important for adaptations required to reestablish appropriate neuronal connections and functions (Payne et al., 2003; Toyoda et al., 2003).

Although protein and mRNA expression levels in tissue are clearly reduced under these pathological conditions, it is not clear whether KCC2 activity is also subject to modulation via direct phosphorylation/dephosphorylation during neuronal stress (Payne et al., 2003). In peripheral tissues, different kinases and phosphatases can modify swelling or vasodilator-induced cationchloride transport; however, the specific pathways involved depend somewhat on cellular origin and experimental conditions (for review, see Adragna et al., 2004), and there is an array of different transporters expressed in these tissues (Payne et al., 2003). In mature hippocampal neurons, activation of receptor tyrosine kinases, in response to either neurotrophins or epileptic activity, rapidly decreases KCC2 mRNA levels and surface expression producing a corresponding depolarizing shift in the 
GABA response (Rivera et al., 2004). The rapid turnover rate of KCC2 $(\tau \sim 20 \mathrm{~min})$ suggests that changes in surface expression may be a dominant way in which KCC2 activity is regulated (Rivera et al., 2004). In immature hippocampal neurons, however, KCC2 can be present in cells without functional $\mathrm{KCC} 2 \mathrm{Cl}^{-}$ transport. Moreover, it may be activated by a broad spectrum kinase inhibitor, staurosporine, or by activation of tyrosine kinases (Kelsch et al., 2001; Khirug et al., 2005). Furthermore, recent studies have demonstrated that postsynaptic spiking activity was capable of causing a rapid and sustained downregulation of KCC2 activity via a $\mathrm{Ca}^{2+}$ and protein kinase $\mathrm{C}$-dependent mechanism (Fiumelli et al., 2005). Hence it would appear that KCC2 activity can be regulated by different cellular kinases and phosphatases signaling cascades, independent of changes in cellular mRNA or protein levels, although it is unclear whether the phosphorylation state of KCC2 itself is modified.

In the present study, we have therefore investigated the hypothesis that neuronal stress can modify KCC2 tyrosine phosphorylation state and functional activity, independent of changes in expression levels.

\section{Materials and Methods}

All relevant experimental protocols were approved by the Ethics Review Committee for Animal Experimentation of the Japanese Physiological Society.

Hippocampal cultures. Embryos were removed from pregnant Wistar rats at embryonic day 19 (E19) under ether anesthesia, and their hippocampi were dissected out and incubated in Earle's balanced salt solution containing papain ( $16 \mathrm{U} / \mathrm{ml}$; Funakoshi, Tokyo, Japan) for $20 \mathrm{~min}$ at $32^{\circ} \mathrm{C}$. Single cells were subsequently isolated by trituration with a $5 \mathrm{ml}$ plastic pipette and plated onto either $0.2 \%$ polyethyleneimine-coated glass coverslips (for electrophysiological and immunocytochemistry) or into $2 \mathrm{ml}$ culture flasks (for biochemical experiments and cell viability assay), also coated with polyethyleneimine, and maintained in Neurobasal medium containing $0.5 \mathrm{~mm}$ L-glutamine and B27 supplement (Invitrogen, Tokyo, Japan) at $37^{\circ} \mathrm{C}$ and $5 \% \mathrm{CO}_{2}$. Cell cultures were fed once a week by replacing one-half of the above medium with fresh medium and used for experiments between 4 and $25 \mathrm{~d}$ in vitro (DIV) as indicated.

Electrical measurements. Electrical measurements were performed using the gramicidin-perforated patch-clamp recording technique (Kakazu et al., 2000; Ueno et al., 2002). The resistance between the patch pipette filled with the internal solution and the reference electrode in the normal external solution was 3-5 M $\Omega$. Ionic currents were measured with a patch-clamp amplifier (EPC-7; List Biologic, Campbell, CA), and recorded with a sampling frequency of $10 \mathrm{kHz}$ after low-pass filtering at 3 $\mathrm{kHz}$. Currents were recorded, and voltage protocols applied, using pClamp software (Clampex 9; Molecular Devices, Union City, CA). Reversal potentials of GABA-activated currents $\left(E_{\mathrm{GABA}}\right)$ were recorded using voltage ramps of $\pm 300 \mathrm{mV}$ in amplitude and of $1 \mathrm{~s}$ duration, applied to the neuron from a holding potential $\left(V_{\mathrm{H}}\right)$ of $-50 \mathrm{mV}$ (Nabekura et al., 1996; Kakazu et al., 1999). $E_{\mathrm{GABA}}$ was taken as the potential at which current responses to voltage ramps, applied just before and during GABA application, intersected. Current-voltage curves, and data analysis, were done using Clampfit 9 (Molecular Devices).

Western blots. Cells cultured under the specified conditions were harvested by washing and subsequent scraping cell cultures with a solution containing the following (in $\mathrm{mM}$ ): $137 \mathrm{NaCl}, 2.68 \mathrm{KCl}, 8.1 \mathrm{Na}_{2} \mathrm{HPO}_{4}$, $1.47 \mathrm{KH}_{2} \mathrm{PO}_{4}$. This solution was centrifuged for $10 \mathrm{~min}$ at $1000 \mathrm{rpm}$ at $4^{\circ} \mathrm{C}$. For quantification of KCC2 and $\beta$-actin, the cell pellets were suspended in $0.25 \mathrm{ml}$ of buffer (containing $50 \mathrm{~mm}$ Tris-HCl, pH 7.5, $150 \mathrm{~mm}$ $\mathrm{NaCl}, 1 \%$ Nonidet P-40, $0.5 \%$ sodium deoxycholate, and protease inhibitor; Roche, Mannheim, Germany; and phosphatase inhibitor mixture 2; Sigma, St. Louis, MO) and sonicated on ice for $30 \mathrm{~s}$. The cell lysates were centrifuged for $30 \mathrm{~min}$ at $15,000 \mathrm{rpm}$ at $4^{\circ} \mathrm{C}$, and the supernatant was collected. For quantification of KCC2 and phosphorylated KCC2, the cell pellets were suspended in $1 \mathrm{ml}$ of buffer (containing $50 \mathrm{~mm}$ Tris- $\mathrm{HCl}, \mathrm{pH}$ 7.5, $150 \mathrm{~mm} \mathrm{NaCl}, 1 \%$ Nonidet P-40, 0.5\% sodium deoxycholate, and protease inhibitor; Roche; and phosphatase inhibitor mixture 2; Sigma) and sonicated on ice for $30 \mathrm{~s}$. The cell lysates were centrifuged for $10 \mathrm{~min}$ at $15,000 \mathrm{rpm}$ at $4^{\circ} \mathrm{C}$, and the supernatant was collected and mixed with protein agarose $\mathrm{A}$ at $4^{\circ} \mathrm{C}$ on a rocking platform, before additional centrifugation for $1 \mathrm{~min}$ at 12,000 rpm. Anti-KCC2 antibody and protein agarose A were sequentially added to the supernatant before incubating overnight, all at $4^{\circ} \mathrm{C}$ on a rocking platform. The pellet was washed multiple times, first with buffer containing $50 \mathrm{~mm}$ Tris- $\mathrm{HCl}, \mathrm{pH}$ 7.5, $150 \mathrm{~mm}$ $\mathrm{NaCl}, 1 \%$ Nonidet P- $40,0.5 \%$ sodium deoxycholate, and protease inhibitor (Roche) and phosphatase inhibitor mixture 2 (Sigma), and then containing $50 \mathrm{~mm}$ Tris- $\mathrm{HCl}$, pH 7.5, $500 \mathrm{~mm} \mathrm{NaCl}, 0.1 \%$ Nonidet P-40, $0.05 \%$ sodium deoxycholate, and then with $10 \mathrm{~mm}$ Tris- $\mathrm{HCl}, \mathrm{pH} 7.5$, $0.1 \%$ Nonidet P- $40,0.05 \%$ sodium deoxycholate, and then these samples were heated to $100^{\circ} \mathrm{C}$ in SDS sample buffer for $5 \mathrm{~min}$. The protein concentrations were determined with a BCA protein assay reagent kit (Pierce, Rockford, IL). The same amount of protein was applied to each lane in all Western blotting experiments, being $2 \mu \mathrm{g}$ for detecting KCC2 and $\beta$-actin, and $25 \mu \mathrm{g}$ for the immunoprecipitate Western blots to quantify the phosphorylated KCC2 and total KCC2. The sample was run through a $7.5 \%$ SDS-PAGE (Bio-Rad, Hercules, CA) to separate KCC2 and phosphorylated KCC2 and $\beta$-actin, which were transferred to a Immobilon $\mathrm{P}$ (Millipore, Bedford, MA), and incubated for $1 \mathrm{~h}$ with $1 \%$ bovine serum albumin (BSA) in a TBS-T solution composed of $20 \mathrm{~mm}$ Tris, $\mathrm{pH}$ 7.6, $137 \mathrm{~mm} \mathrm{NaCl}$, and $0.1 \%$ Tween 20. The membranes were incubated overnight with anti-KCC2 antibody (Upstate Biotechnology, Lake Placid, NY) diluted at 1:750, anti-phosphotyrosine antibody (clone 4G10) (Upstate Biotechnology) diluted at 1:500, anti-phosphotyrosine antibody (clone PY20) (Sigma) diluted at 1:2000, or anti- $\beta$-actin antibody (Sigma) diluted at 1:10,000. All antibody dilutions and incubations were done in TBS-T solution containing 1\% BSA. After washing the membranes four times for 15 min each with TBS-T, they were further incubated for $1 \mathrm{~h}$ with horseradish peroxidase-conjugated secondary antibody in TBS-T buffer. Protein was visualized using an ECL detection system (Amersham Biosciences, Piscataway, NJ). The size of protein was identified using a protein size marker (Invitrogen). The band of KCC2 was detected at $150 \mathrm{kDa}$. The relative band intensities were determined by densitometry using NIH Image.

Cell surface biotinylation assay. After treatment of cultured neurons for $1 \mathrm{~h}$ with the appropriate experimental condition $\left(\mathrm{H}_{2} \mathrm{O}_{2}\right.$ with and without $\mathrm{Na}_{3} \mathrm{VO}_{4}$ ), cells were immediately washed twice with ice-cold PBS. Cell surface proteins were biotinylated using $0.5 \mathrm{mg} / \mathrm{ml}$ cell impermeant, noncleavable sulfo-NHS-Biotin (Pierce) in PBS for $30 \mathrm{~min}$ at $4^{\circ} \mathrm{C}$. The reaction was stopped with quenching solution (Pierce), and cells were harvested in $10 \mathrm{ml}$ of TBS by scraping. Cells were collected by centrifugation at $500 \times g$ for $3 \mathrm{~min}$ and rinsed with $5 \mathrm{ml}$ of TBS and collected again by centrifugation at $500 \times \mathrm{g}$ for $3 \mathrm{~min}$. Cells were dissolved in 250 $\mu \mathrm{l}$ of lysis buffer (Pierce) containing protease inhibitor mixture (Sigma). Cell lysate was sonicated for $30 \mathrm{~s}$, and then centrifuged at 10,000 $\times \mathrm{g}$ for $2 \mathrm{~min}$ at $4^{\circ} \mathrm{C}$. Supernatants was reacted with Neutravidin Gel (Pierce) for $60 \mathrm{~min}$ at room temperature, before triplicate washes with wash buffer (Pierce) containing the protease inhibitor mixture (Sigma). Proteins were eluted by incubating with SDS-PAGE sample buffer containing 50 mM DTT for 60 min before being subjected to Western blotting.

${ }^{32} \mathrm{P}$ labeling assay for KCC2 phosphorylatyion. Cultured hippocampal neurons (20 DIV) were incubated for $30 \mathrm{~min}$ in sodium phosphate-free DMEM (P-free medium; Invitrogen), before labeling with P-free medium containing $\left[{ }^{32} \mathrm{P}\right]$ orthophosphate $(150 \mu \mathrm{Ci}$ per $60 \mathrm{~mm}$ dish; PerkinElmer Life Sciences, Boston, MA) for $2 \mathrm{~h} . \mathrm{H}_{2} \mathrm{O}_{2}(50 \mu \mathrm{M})$ was then added to the medium for another $60 \mathrm{~min}$. The cells were then washed three times with ice-cold PBS, and lysed with a lysis buffer. The lysates obtained by centrifugation were subjected to immunoprecipitation with anti-KCC2 antibody and rabbit control IgG, followed by the addition of $20 \mu \mathrm{l}$ of a $50 \%$ slurry of protein G-Sepharose beads. The immunoprecipitates were analyzed by SDS-PAGE, followed by autoradiography (BAS2500; Fuji Film, Tokyo, Japan).

Immunocytochemistry. Cells cultured on coverslips were fixed by replacing medium with a solution of $4 \%$ paraformaldehyde in $0.1 \mathrm{~mm}$ PBS, $\mathrm{pH} 7.2$, and incubated for $40 \mathrm{~min}$ at room temperature (RT), and then washed with TNBS buffer $(0.3 \%$ Triton X-100 and $1 \%$ normal goat se- 
rum in PBS). Subsequently, cells were permeabilized by incubation for $1 \mathrm{~h}(\mathrm{RT})$ in a blocking solution containing 2\% BSA in TNBS buffer. Anti-KCC2 antibody (at 1:325 dilution) and anti-microtubuleassociated protein 2 (MAP-2) antibody (Upstate Biotechnology; at 1:100 dilution) was added and incubated overnight at $4^{\circ} \mathrm{C}$ (Williams et al., 1999) before being rinsed with TNBS buffer and incubated with Alexa 488594 secondary fluorescent antibodies (Invitrogen, Eugene, OR), before final rinsing and addition of Slowfade (Invitrogen). Fluorescent images were obtained using a laser-scanning confocal microscope (Leica Microsystems, Wetzlar, Germany).

In utero electroporation. Timed-pregnant Sprague Dawley rats were anesthetized with sodium pentobarbital $(0.625 \mathrm{mg}$ per $10 \mathrm{~g}$ of body weight, i.p.), their abdominal cavities were cut open, and the uterine horns were exposed. Approximately $1-2 \mu \mathrm{l}$ of DNA solution was injected into the lateral ventricle of embryos at E15-E17 using a glass micropipette. Each embryo within its uterus was placed between tweezer-type electrodes (CUY650-P5; NEPA Gene, Chiba, Japan). For targeting the cortical ventricular zone, the angle of inclination of the electrode paddles, with respect to the horizontal plane of the brain, was zero. Square electric pulses ( $50 \mathrm{~V} ; 50 \mathrm{~ms}$ ) were applied to the electrodes five times, at $75 \mathrm{~ms}$ intervals, using an electroporator (CUY21E; NEPA Gene). To avoid excessive temperature loss, only a few embryos were exposed at any one time, and care was taken to quickly place them back into the abdominal cavity after electroporation. Once all embryos were electroporated, the wall and skin of the abdominal cavity were sutured, and embryos were allowed to develop normally. The KCC2 vector was a EGFP-IRES-KCC2 plasmid construct. Plasmid DNA was purified with an Endofree plasmid maxi kit (Qiagen, Valencia, CA), and resuspended in $10 \mathrm{~mm}$ Tris- $\mathrm{HCl}$, $\mathrm{pH}$ 8.0. Before the procedure, plasmid DNA was diluted to $1 \mu \mathrm{g} / \mu \mathrm{l}$ in PBS, and Fast Green solution was added to a final concentration of $0.03 \%$ to monitor the injection.

Data analysis. Values are the mean $\pm \mathrm{SE}$ of at least three or four independent experiments. Statistical examination was performed by one-way factorial ANOVA combined with Scheffe's test for all comparison pairs. Differences with $p<0.05$ were considered significant.

\section{Results}

\section{The effects of neuronal stressors on KCC2 protein} expression and phosphorylation in primary hippocampal neuron cultures

To investigate changes in KCC2 protein expression and phosphorylation during neuronal stress, we used an in vitro system generating primary cultures of hippocampal neurons isolated from embryonic E19 rats. A variety of neuronal traumas have been shown previously to induce disruptions in $\mathrm{Cl}^{-}$homeostasis, $E_{\mathrm{GABA}}$, and/or downregulation of KCC2 mRNA or protein expression. We initially investigated the effects of $\mathrm{H}_{2} \mathrm{O}_{2}$ incubation, a model of oxidative stress and free radical-induced neuronal damage (Whittemore et al., 1995). Figure 1, $A$ and $B$, shows that prolonged incubation with $\mathrm{H}_{2} \mathrm{O}_{2}(50 \mu \mathrm{M})$ results in a decrease in expression levels of KCC2 protein in the membrane fraction, with this decrease becoming evident with $\mathrm{H}_{2} \mathrm{O}_{2}$ incubation periods $>3 \mathrm{~h}$. There was little change in levels of $\beta$-actin over the same time period. In contrast, the level of tyrosinephosphorylated KCC2 decreases more rapidly, and a significant decrease in the ratio of tyrosine phosphorylated KCC2 to total KCC2 was seen at the earliest time point examined (1 h incubation) (Fig. $1 C, D)$. In the experiment illustrated by Figure $1 C$, two samples of $2 \mu \mathrm{g}$ of protein were applied to two separate gels of equal composition, which were then stained as described in Materials and Methods. After $3 \mathrm{~h} \mathrm{H}_{2} \mathrm{O}_{2}$ incubation, total KCC2 levels were $88 \pm 4.6 \%$ of control levels (before $\mathrm{H}_{2} \mathrm{O}_{2}$ application), whereas the ratio of tyrosine-phosphorylated KCC2 to total KCC2 declined to $16.7 \pm 1.2 \%$ of control levels $(n=4)$. A qualitatively similar rapid loss of tyrosine-phosphorylated KCC2 in response to $\mathrm{H}_{2} \mathrm{O}_{2}$ was seen using a tyrosine-phosphorylated

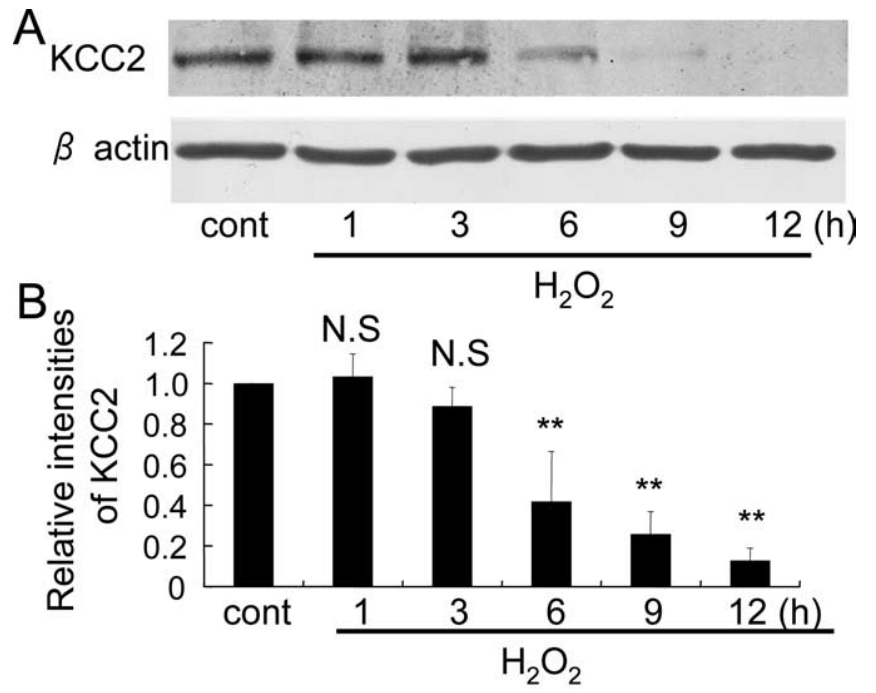

\section{Phospho- $\mathrm{KCC} 2$} Total$\mathrm{KCC} 2$
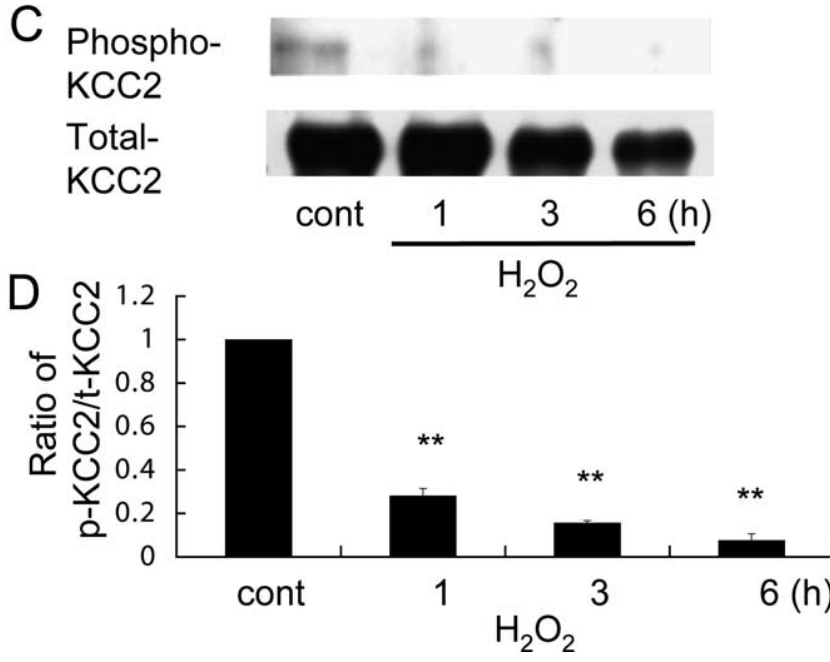

Figure 1. The time course of $\mathrm{KCC} 2$ protein expression and phosphorylation ratio in cultured hippocampal neurons during oxidative stress. $\boldsymbol{A}$, Western blots showing total KCC expression in membranes of hippocampal neurons, before (cont) and 1-12 h after treatment of hippocampal cultures (21-25 DIV) with $\mathrm{H}_{2} \mathrm{O}_{2}(50 \mu \mathrm{m})$. Equal amounts of protein $(2 \mu \mathrm{g})$ were applied to each lane. The bottom panel shows expression levels of the control protein, $\beta$-actin, in parallel experiments on membranes prepared from the same cell cultures. $\boldsymbol{B}$, Averaged optical density of total membrane $\mathrm{KCC} 2$ expression, at $1-12 \mathrm{~h} \mathrm{H}_{2} \mathrm{O}_{2}$ incubation, expressed relative to control levels of KCC2. Each column represents the mean and SEM of data from four experiments. $\boldsymbol{C}$, Western blots showing tyrosine-phosphorylated KCC2 (top row) and total KCC2 expression in hippocampal neurons, before (cont) and 1- $6 \mathrm{~h}$ after treatment of hippocampal cultures with $\mathrm{H}_{2} \mathrm{O}_{2}(50 \mu \mathrm{m})$. The same amount of protein $(25 \mu \mathrm{g})$ was added to each lane, and the same samples were used to detect both total KCC2 and phosphorylated KCC2. D, Averaged ratio of optical density of tyrosine-phosphorylated KCC2 relative to total KCC2 expression (bottom row), at $1-6 \mathrm{~h}$ after $\mathrm{H}_{2} \mathrm{O}_{2}$ incubation. Each column represents the mean and SEM of data from four experiments. The relative amount of tyrosine-phosphorylated $\mathrm{KCC} 2$ is markedly decreased by $1 \mathrm{~h}$ after treatment with $\mathrm{H}_{2} \mathrm{O}_{2}$, before any change is observed in total $\mathrm{KCC} 2$ expression levels. ${ }^{* *} p<0.01$ compared with control; N.S, not significantly different from control.

KCC2 antibody from a different clone PY20 (Sigma), and when KCC2 phosphorylation state was identified with autoradiography with ${ }^{32} \mathrm{P}$ labeling (supplemental Fig. 1, available at www. jneurosci.org as supplemental material).

Our preliminary experiments had indicated that inducing seizure activity by injection of kainic acid resulted in a gradual decrease in KCC2 protein levels in subsequently excised hippocampal membranes that was preceded by more rapid decreases in tyrosine phosphorylation (data not shown). Hence we also investigated models of in vitro epileptic activity using our hippocampal 


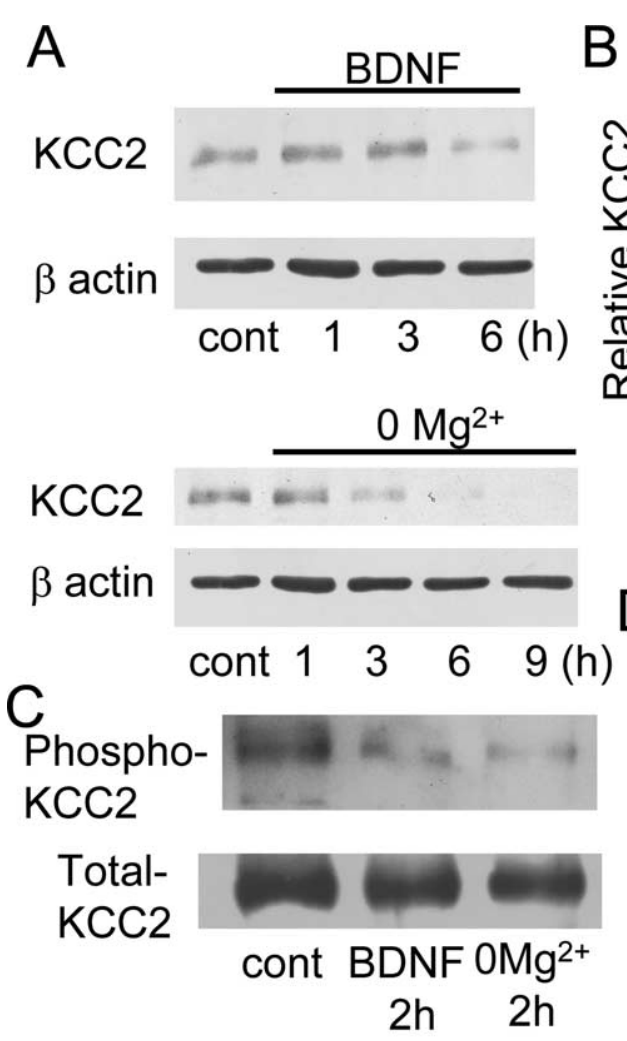

B
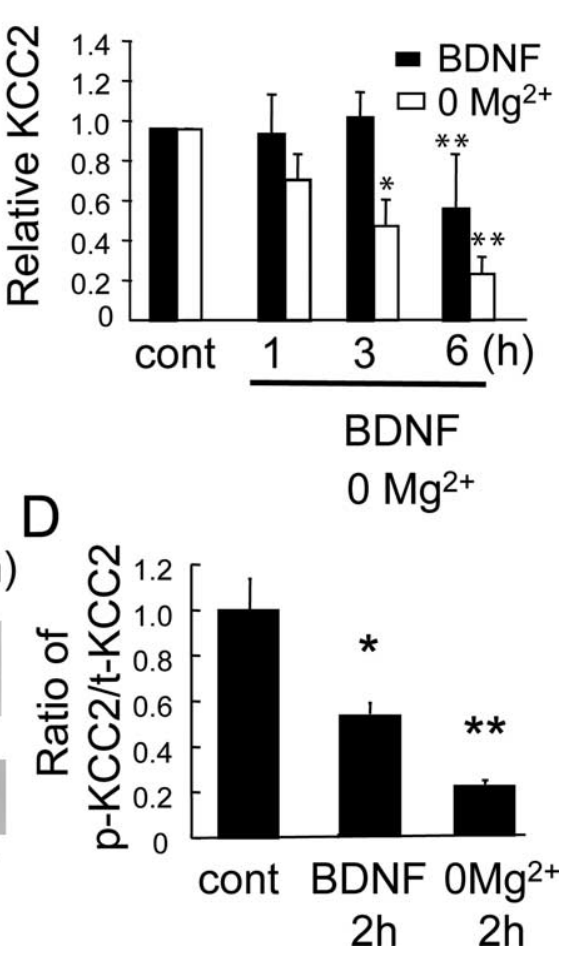

Figure 2. The time course of KCC2 protein expression and phosphorylation ratio in cultured hippocampal neurons during two different in vitro models of epilepsy. $\boldsymbol{A}$, Western blots showing total KCC2 expression, and control levels of $\beta$-actin expression in parallel experiments on membranes from the same cell cultures, before (cont) and 1- $6 \mathrm{~h}$ after incubation with BDNF ( $20 \mathrm{ng} / \mathrm{ml}$; top panels) or 1-9 h after incubation with $0 \mathrm{Mg}^{2+}$ (bottom panels). $\boldsymbol{B}$, Averaged optical density of total membrane KCC2 expression, at 1-6 h incubation with BDNF or $0 \mathrm{Mg}^{2+}$, expressed relative to control levels of $\mathrm{KCC}$. Each column represents the mean and SEM of data from three experiments. C, Western blots showing total KCC2 (bottom panel) and tyrosine-phosphorylated $\mathrm{KCC}$ (top panel) expression in control conditions (cont) and at $2 \mathrm{~h}$ after BDNF and $0 \mathrm{Mg}^{2+}$ incubation. $\boldsymbol{D}$, Averaged ratio of optical density of tyrosine-phosphorylated KCC2 relative to total $K C C 2$ expression, in control conditions, and at $2 \mathrm{~h}$ after BDNF or $0 \mathrm{Mg}^{2+}$ incubation. Each column represents the mean and SEM of data from four experiments. The relative amount of tyrosinephosphorylated KCC2 is markedly decreased before any change is observed in total $\mathrm{KCC} 2$ expression levels. ${ }^{* *} p<0.01,{ }^{*} p<0.05$ compared with control.

cultures. The exogenous application of BDNF, a neurotrophin whose expression and release is increased during in vivo seizure activity, has also been shown to induce a decrease in KCC2 mRNA and protein expression and an impairment of $\mathrm{Cl}^{-}$extrusion in hippocampal neurons in vitro (Rivera et al., 2002). Incubation of isolated neurons or slices with $0 \mathrm{Mg}^{2+}$ has been shown to elicit hyperexcitability in vitro (Rivera et al., 2004). Figure 2, A and $B$, shows KCC2 protein levels in hippocampal neurons are unchanged at 1 and $3 \mathrm{~h}$ after incubation with BDNF, but downregulated after $6 \mathrm{~h}$ BDNF incubation. KCC2 protein levels are also downregulated after $3 \mathrm{~h}$ incubation in $\mathrm{Mg}^{2+}$-free culture medium. Neither of these treatments produced any change in the expression levels of $\beta$-actin. These treatments also resulted in a reduced tyrosine phosphorylation of $\mathrm{KCC} 2$, and, for BDNF incubation, this was observed at time points before changes in KCC2 protein levels (Fig. 2C,D). The ratio of tyrosinephosphorylated KCC2 to total KCC2 protein was reduced by $\sim 50 \% 2 \mathrm{~h}$ after BDNF application, at a time when total KCC2 was unchanged. Although total KCC2 expression levels were decreased by $\sim 50 \%$ after $3 \mathrm{~h}$ incubation in $\mathrm{Mg}^{2+}$-free culture medium, the ratio of tyrosine-phosphorylated KCC2 to total KCC2 protein decreased by an even greater amount (by $77 \pm 4 \% ; n=4$ ) after just $2 \mathrm{~h}$ incubation.
Time course of KCC2 function in primary cultured hippocampal neurons exposed to $\mathrm{H}_{2} \mathrm{O}_{2}$

Decreases in KCC2 protein expression levels in cultured hippocampal neurons result in disruption of $\mathrm{Cl}^{-}$homeostasis, increases in intracellular $\mathrm{Cl}^{-}$, and corresponding depolarizing shifts in $E_{\mathrm{GABA}}$ (Rivera et al., 2002; Khirug et al., 2005; Zhu et al., 2005). We therefore measured the time course of changes in $E_{\mathrm{GABA}}$ in cultured neurons exposed to $\mathrm{H}_{2} \mathrm{O}_{2}$ to investigate whether changes in $\mathrm{KCC} 2$ tyrosine phosphorylation state had functional consequences. Experiments were conducted on neurons after 21 DIV, a time when cultured hippocampal neurons have developed adult-like pattern of KCC2 protein levels and activity (Fiumelli et al., 2005; Khirug et al., 2005), and we used the gramicidin-perforated patchclamp technique to preserve intracellular $\mathrm{Cl}^{-}$(Kakazu et al., 1999, 2000). Voltage ramps were applied before and after bath application of GABA $(30 \mu \mathrm{M})$, and $E_{\mathrm{GABA}}$ was measured before, and $1,3,6$, and $9 \mathrm{~h}$ after application of $\mathrm{H}_{2} \mathrm{O}_{2}$ (Fig. 3). In control conditions, GABA application produced a large outward current at a $V_{\mathrm{H}}$ of $-50 \mathrm{mV}$ which reversed at $-71 \pm 7.8 \mathrm{mV}$ $(n=5)$. Furosemide shifted $E_{\mathrm{GABA}}$ to $-55 \pm 3 \mathrm{mV}(n=5)$. In addition, the replacement of intracellular $\mathrm{K}^{+}$with $\mathrm{Cs}^{+}$ (Kakazu et al., 1999, 2000) also shifted $E_{\mathrm{GABA}}$ to $-47 \pm 3 \mathrm{mV}$, confirming that a furosemide- and $\mathrm{K}^{+}$-sensitive mechanism (i.e., KCC2) plays an important role in maintaining low intracellular $\mathrm{Cl}^{-}$in adult hippocampal neurons.

One hour after application of $\mathrm{H}_{2} \mathrm{O}_{2}$, the outward current response to GABA had decreased and $E_{\mathrm{GABA}}$ already showed a shift to more positive potentials (Fig. 3), indicating that loss of tyrosine phosphorylation of KCC2 results in functional downregulation of KCC2 and an increase in intracellular $\mathrm{Cl}^{-}$. During continued incubation with $\mathrm{H}_{2} \mathrm{O}_{2}, E_{\mathrm{GABA}}$ shifted to more positive potentials with the GABA response at a $V_{\mathrm{H}}$ of $-50 \mathrm{mV}$, eventually being converted into an inward current. There seemed to be two phases of the change in $E_{\mathrm{GABA}}$ (Fig. 3 ), an early change occurring within $1 \mathrm{~h}$ of $\mathrm{H}_{2} \mathrm{O}_{2}$ treatment, and a more gradual depolarizing shift in $E_{\mathrm{GABA}}$ that occurred between 6 and $9 \mathrm{~h}$ after application of $\mathrm{H}_{2} \mathrm{O}_{2}$, presumably corresponding to a time when total KCC2 protein levels are decreased.

\section{Role of protein phosphatases in the loss of KCC2 tyrosine phosphorylation}

A loss of tyrosine phosphorylation of KCC2 may result from an increased activity of tyrosine phosphatases and/or a decreased activity of tyrosine kinases. To investigate potential underlying mechanisms, we examined the effects of sodium vanadate $\left(\mathrm{Na}_{3} \mathrm{VO}_{4}\right)$, a specific inhibitor of tyrosine phosphatases (Swarup et al., 1982), on the oxidative stress-induced change in KCC2 tyrosine phosphorylation ratio. Incubation for $3 \mathrm{~h}$ with both $\mathrm{Na}_{3} \mathrm{VO}_{4}(100 \mu \mathrm{M})$ and $\mathrm{H}_{2} \mathrm{O}_{2}(50 \mu \mathrm{M})$ did not significantly affect 

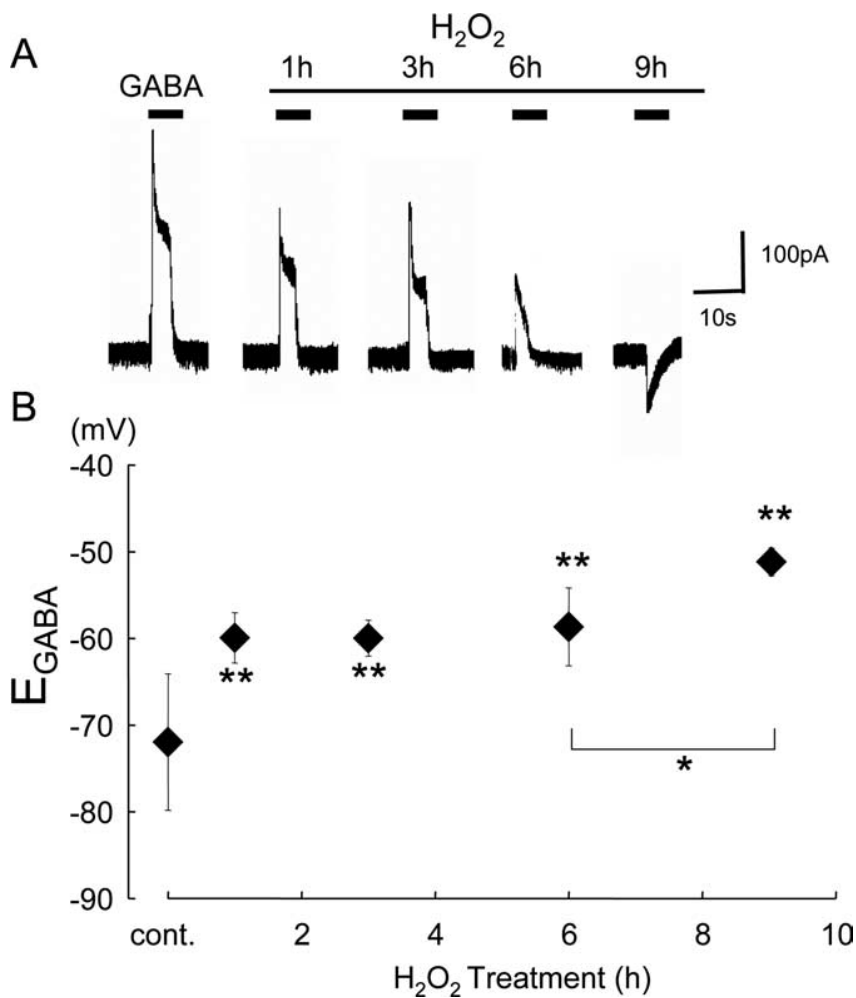

Figure 3. Changes in $E_{G A B A}$ in primary cultured hippocampal neurons during incubation with $\mathrm{H}_{2} \mathrm{O}_{2}$. A, Representative whole-cell membrane currents recorded using the gramicidinperforated patch technique, in response to application of GABA (30 $\mu$ m; thick horizontal bars), recorded at a $V_{\mathrm{H}}$ of $-50 \mathrm{mV}$, before and at different times during $\mathrm{H}_{2} \mathrm{O}_{2}(50 \mu \mathrm{M})$ incubation as indicated. The outward currents gradually decreased in amplitude, and eventually the response to GABA changed to an inward current response after $9 \mathrm{~h}$ incubation with $\mathrm{H}_{2} \mathrm{O}_{2}$. B A Averaged $E_{G A B A}$ measured in neurons incubated with $\mathrm{H}_{2} \mathrm{O}_{2}$ for up to $9 \mathrm{~h}$ as indicated. Each data point represents the mean and $S E M$ of $E_{G A B A}$ recorded in five neurons. $\mathrm{H}_{2} \mathrm{O}_{2}$ incubation caused $E_{G A B A}$ to rapidly $(<1 \mathrm{~h})$ shift to a more depolarized level resulting in a reduced outward current response at a $V_{\mathrm{H}}$ of $-50 \mathrm{mV}$. Prolonged ( $>6 \mathrm{~h}$ ) incubation with $\mathrm{H}_{2} \mathrm{O}_{2}$ caused an additional depolarizing shift in $E_{\mathrm{GABA}}$, which could even result in an inward current at a $V_{\mathrm{H}}$ of $-50 \mathrm{mV}$. ${ }^{* *} p<0.01$ compared with the control $E_{\mathrm{GABA}}{ }^{*}{ }^{*} p<0.05$ comparing $E_{\mathrm{GABA}}$ at 6 and $9 \mathrm{~h} .\left[\mathrm{Cl}^{-}\right]_{0}, 159 \mathrm{~mm}$.

total KCC2 expression levels (supplemental Fig. 2, available at www.jneurosci.org as supplemental material) $(n=4)$ (see also Fig. 4A). Incubation of cultured hippocampal neurons with $\mathrm{Na}_{3} \mathrm{VO}_{4}(100 \mu \mathrm{M})$ for $1-3 \mathrm{~h}$, induced an approximate doubling of the proportion of KCC2 that was tyrosine phosphorylated (Fig. $4 B$; supplemental Fig. $1 B$, available at www.jneurosci.org as supplemental material), indicating a basal level of tyrosine kinase and phosphatase activity in control conditions. When neurons were incubated for 1 or $3 \mathrm{~h}$ with both $\mathrm{Na}_{3} \mathrm{VO}_{4}(100 \mu \mathrm{M})$ and $\mathrm{H}_{2} \mathrm{O}_{2}$ $(50 \mu \mathrm{M})$, the proportion of KCC2 that was tyrosine phosphorylated increased markedly, by $\sim 4$ - and 10 -fold, respectively (Fig. $4 \mathrm{~A}$ ). In addition, an incubation with $\mathrm{H}_{2} \mathrm{O}_{2}$, and other possible tyrosine phosphatase blockers (e.g., phenylarsine oxide and $\mathrm{Na}_{2} \mathrm{MoO}_{4}$ ), but not a serine-threonine phosphatase blocker, okadaic acid, also increased the phosphorylated KCC2 (supplemental Fig. 3, available at www.jneurosci.org as supplemental material). This is in stark contrast to the effects of $\mathrm{H}_{2} \mathrm{O}_{2}$ alone in causing a reduced proportion of phosphorylated KCC2 (Figs. 1, $4 D$ ) and suggests that oxidative stress stimulates an increased rate of both tyrosine phosphorylation and dephosphorylation (i.e., increased turnover), with dephosphorylation being dominant and the increased phosphorylation apparent only once phosphatase activity is blocked. The self-consistency of these results re-

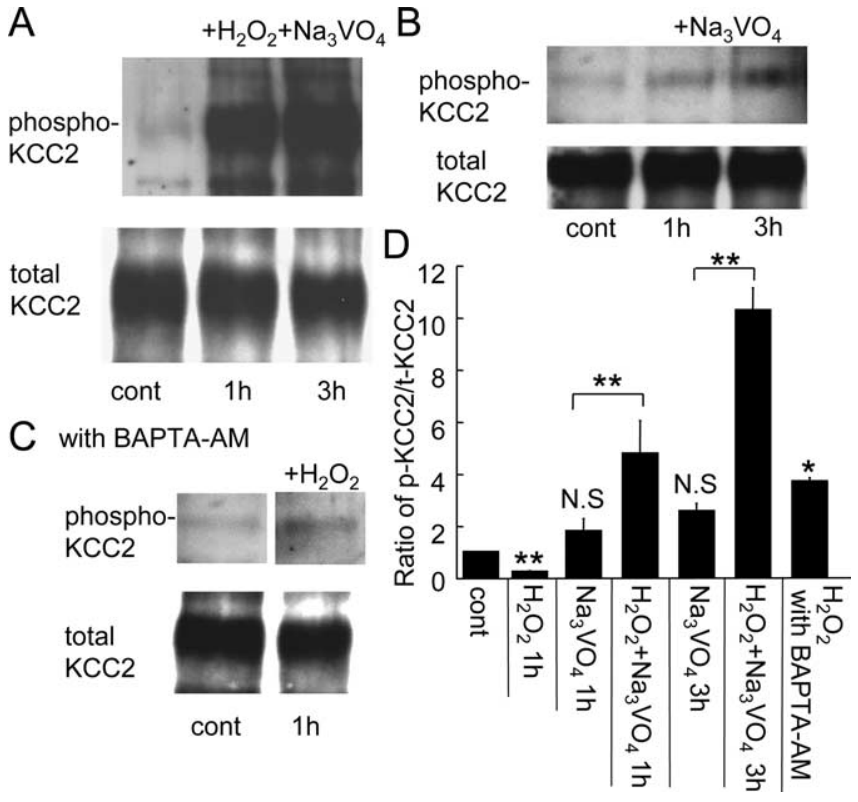

Figure 4. Effects of phosphatase inhibition and $\mathrm{Ca}^{2+}$ chelation on relative tyrosine phosphorylation of $K C C 2 . A, B$, Western blots showing expression levels of tyrosine-phosphorylated KCC2 (top rows) and total KCC2 (bottom rows) in control conditions and at 1 and $3 \mathrm{~h}$ after application of the phosphatase inhibitor $\mathrm{Na}_{3} \mathrm{VO}_{4}(100 \mu \mathrm{M})$ with $(\boldsymbol{A})$ and without $(\boldsymbol{B}) \mathrm{H}_{2} \mathrm{O}_{2}$. C, Expression levels of tyrosine-phosphorylated KCC2 (top row) and total KCC2 (bottom row) in control conditions and at $1 \mathrm{~h}$ after application of $\mathrm{H}_{2} \mathrm{O}_{2}$ in the presence of BAPTA-AM $(10 \mu \mathrm{M})$. D, Averaged optical density of the ratio of tyrosine-phosphorylated $\mathrm{KCC} 2$ relative to total $\mathrm{KCC} 2$ expression levels in membrane of cultured hippocampal neurons incubated in $\mathrm{Na}_{3} \mathrm{VO}_{4}(100 \mu \mathrm{M})$ with or without $\mathrm{H}_{2} \mathrm{O}_{2}\left(1\right.$ and $3 \mathrm{~h}$ ), or incubated with $\mathrm{H}_{2} \mathrm{O}_{2}$ and BAPTA-AM. Ratios are expressed relative to that in control conditions before incubation with any test compounds. A total of 25 $\mu \mathrm{g}$ of protein was added to each lane, and the same samples were analyzed for both total $\mathrm{KCC} 2$ and tyrosine-phosphorylated KCC2. Columns show mean and SEM of data from four experiments. ${ }^{*} p<0.01$ comparing $\mathrm{Na}_{3} \mathrm{VO}_{4}$, incubation with and without $\mathrm{H}_{2} \mathrm{O}_{2}$; ${ }^{*} p<0.05$ compared with control; N.S, not significantly different from control.

quires that $\mathrm{H}_{2} \mathrm{O}_{2}$ stimulates kinase activity, because otherwise the 10-fold stimulation in $\mathrm{H}_{2} \mathrm{O}_{2}+\mathrm{Na}_{3} \mathrm{VO}_{4}$ at $3 \mathrm{~h}$ would be unexplained compared with the very modest stimulation in $\mathrm{Na}_{3} \mathrm{VO}_{4}$ alone and the small decrease by $\mathrm{H}_{2} \mathrm{O}_{2}$ alone as illustrated in Figure $4 D$. Under conditions of intracellular $\mathrm{Ca}^{2+}$ chelation with BAPTA-AM, $\mathrm{H}_{2} \mathrm{O}_{2}$ failed to decrease (and modestly increased) the proportion of phosphorylated KCC2 (Fig. 4C,D), suggesting that the decrease in KCC2 tyrosine phosphorylation and function may be mediated by elevation of intracellular $\mathrm{Ca}^{2+}$.

\section{Cell surface localization of KCC2 in hippocampal primary neuronal cultures in response to neuronal stress}

It has recently been reported that the protein levels of KCC2 in hippocampal slices exposed to either $\mathrm{Mg}^{2+}$-free solution or $\operatorname{BDNF}(100 \mathrm{ng} / \mathrm{ml})$ show a decrease within 1 and $2 \mathrm{~h}$, respectively (Rivera et al., 2002, 2004). The half-life of surface-expressed KCC2 in hippocampal slices exposed to $0 \mathrm{Mg}^{2+}$ was also decreased, from a mean of $\sim 20$ to 10 min (Rivera et al., 2004). Because this suggests a rapid translocation of KCC2 between the plasma membrane and intracellular compartments, we decided to investigate the cellular distribution of KCC2 in control conditions, and after $1 \mathrm{~h}$ incubation with $\mathrm{H}_{2} \mathrm{O}_{2}$, a time corresponding to when tyrosine phosphorylation is markedly reduced but total KCC2 protein is unaffected. We used both confocal microscopy and quantification of biotinylated surface proteins. Typical fluorescent images are shown in Figure 5. In control neurons, KCC2 was expressed on the plasma membrane along the proximal den- 


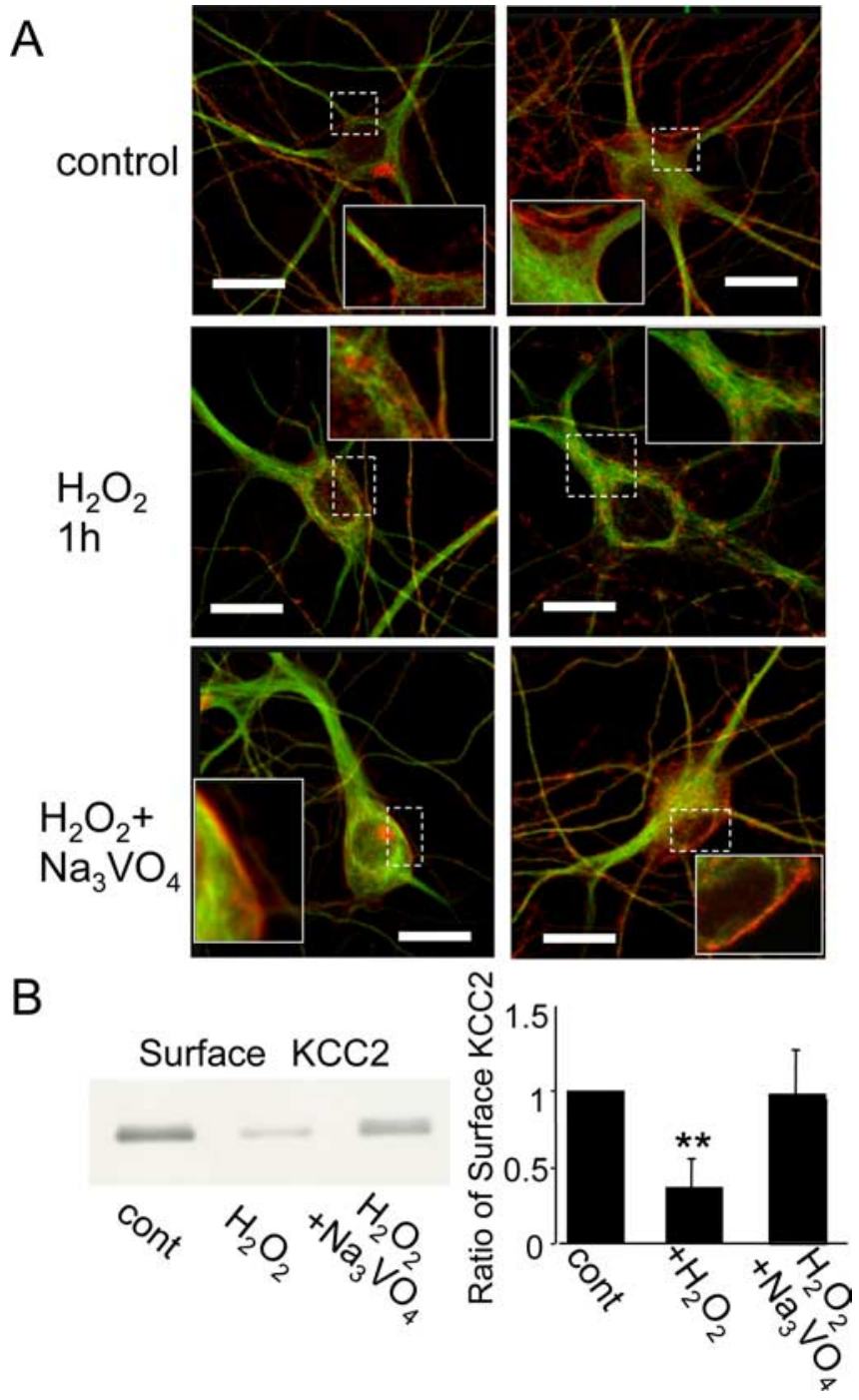

Figure 5. Immunofluorescent staining of the cellular localization of $\mathrm{KCC} 2$ and quantification of cell surface expression of $\mathrm{KCC} 2$ in cultured hippocampal neurons treated with $\mathrm{H}_{2} \mathrm{O}_{2} . \mathrm{A}, \mathrm{KCC} 2$ immunofluorescent images (red) in two control neurons (top panels) with MAP-2 staining (green). Note the staining of KCC2 (represented by red fluorescence) observed on the cell surface throughout the soma and particularly throughout the proximal dendrites. KCC2 immunofluorescent images after $1 \mathrm{~h} \mathrm{H}_{2} \mathrm{O}_{2}$ incubation without (middle panels) and with the phosphatase inhibitor Na vanadate $\left(\mathrm{Na}_{3} \mathrm{VO}_{4}\right)(100 \mu \mathrm{m})$ (bottom panels). Note the loss of surface expression of $\mathrm{KCC} 2$ in response to $\mathrm{H}_{2} \mathrm{O}_{2}$, which was not observed with additional $\mathrm{Na}_{3} \mathrm{VO}_{4}$ incubation. The insets in each panel show an enlargement of the area depicted by the dotted squares. Scale bars, $10 \mu \mathrm{m}$ (for each panel). $\boldsymbol{B}$, Biotinylation assay of cell surface expression of KCC2, in control conditions, and after $1 \mathrm{~h}$ incubation in $\mathrm{H}_{2} \mathrm{O}_{2}$, with and without $\mathrm{Na}_{3} \mathrm{VO}_{4}(100 \mu \mathrm{m})$. The left panel shows a sample Western blot, and the right panel shows averaged optical densities of Western blots from three separate experiments. Error bars indicate SEM. The same total protein $(2 \mu \mathrm{g})$ was applied to each lane. Surface expression of $\mathrm{KCC} 2$ shows a significant decrease in response to $\mathrm{H}_{2} \mathrm{O}_{2}$, which is prevented by $\mathrm{Na}_{3} \mathrm{VO}_{4} .{ }^{* *} p<0.01$ compared with control.

drites and throughout the cell soma (Fig. 5, control). One hour after incubation with $\mathrm{H}_{2} \mathrm{O}_{2}$, most of this surface immunostaining of KCC2 appeared to have been lost (Fig. 5, $\mathrm{H}_{2} \mathrm{O}_{2}$ ). After $1 \mathrm{~h}$ incubation with both $\mathrm{H}_{2} \mathrm{O}_{2}$ and $\mathrm{Na}_{3} \mathrm{VO}_{4}$, however, the surface expression of KCC2 was maintained (Fig. $5 \mathrm{~A}, \mathrm{H}_{2} \mathrm{O}_{2}+\mathrm{Na}_{3} \mathrm{VO}_{4}$ ). The biotinylation assay also clearly demonstrated that $\mathrm{H}_{2} \mathrm{O}_{2}$ incubation resulted in a marked decrease in surface expression of KCC2 that could be prevented by coincubation with $\mathrm{Na}_{3} \mathrm{VO}_{4}$ (Fig. 5B).

\section{Consequences of $\mathrm{KCC} 2$ functional downregulation on neuronal viability}

Although a number of reports, as well as the data above, have indicated functional downregulation of KCC2 in response to neuronal injury or stress (see Introduction), it is not clear what the consequences of changes in KCC2 function are in regard to neuron viability. To begin to address this, we used a coarse, but simple, measure of cell viability, the ability of healthy neurons to exclude the membrane impermeant dye trypan blue. Incubation of cultured neurons with $\mathrm{H}_{2} \mathrm{O}_{2}(50 \mu \mathrm{M})$ led to a loss of cell viability, with $25 \pm 12 \%$ of neurons observed unable to exclude trypan blue (Fig. 6A). Our above results showed that KCC2 function is downregulated by such oxidative stress, and consequently GABA responses become depolarizing. Therefore, we next investigated whether activation or inhibition of $\mathrm{GABA}_{\mathrm{A}}$ receptors during oxidative stress could affect cell viability. Coapplication of the $\mathrm{GABA}_{\mathrm{A}}$ receptor agonist, muscimol $(30 \mu \mathrm{M})$, during $\mathrm{H}_{2} \mathrm{O}_{2}$ incubation, resulted in an increase in the proportion of neurons that could not exclude trypan blue (Fig. 6A), indicating enhanced neuronal death. Conversely, coapplication of the $\mathrm{GABA}_{\mathrm{A}}$ receptor antagonist, 2-(3-carboxypropyl)-3-amino-6-(4-methoxyphenyl)pyridazinium (SR 95531) $(30 \mu \mathrm{M})$, resulted in a decrease in the proportion of neurons that could not exclude trypan blue. Muscimol $(30 \mu \mathrm{M})$ alone did not affect this proportion $(n=3)$. Hence endogenous and exogenous activation of $\mathrm{GABA}_{\mathrm{A}}$ receptors during oxidative stress can exacerbate the loss of cell viability during oxidative stress

We next investigated the consequences of manipulating the levels of KCC2 that become tyrosine dephosphorylated during oxidative stress. Our first approach was to overexpress KCC2, because in neurons with excess transporters, a greater absolute number will maintain tyrosine phosphorylation during oxidative stress. To overexpress KCC2, we generated a pKCC2-IRES-EGFP cDNA construct and transfected rat embryos at E15-E17 with this vector using in utero electroporation. Cortical neuronal cultures were subsequently generated from these transfected embryos at E20. We choose to use in utero-transfected cultures of cortical neurons, as opposed to in vitro transfection of hippocampal neurons, because we could achieve higher transfection rates with this method and considered it to be a less stressful stimulus for the neurons, given that they could recover from the transfection procedure in vivo. To confirm successful overexpression of KCC2, we compared $E_{\mathrm{GABA}}$ in cultured neurons expressing green fluorescent protein (GFP) with control neurons from the same cultures that did not express the GFP construct, at 4-5 DIV, using gramicidin-perforated patch-clamp recordings (Fig. $6 \mathrm{~B}$ ). In control neurons, GABA $(30 \mu \mathrm{M})$ evoked an inward current at a $V_{\mathrm{H}}$ of $-50 \mathrm{mV}$, which reversed at $-47.9 \pm 5.4 \mathrm{mV}$ (Fig. $6 \mathrm{~B}, n=6$ ). This is consistent with previous results in primary hippocampal neuronal cultures derived from embryonic rats, which fail to show a functional KCC2 response until $\sim 2$ weeks in vitro (Kelsch et al., 2001; Fiumelli et al., 2005; Khirug et al., 2005). In contrast, in neurons expressing the construct, GABA induced an outward current at a $V_{\mathrm{H}}$ of $-50 \mathrm{mV}$, which reversed at a more hyperpolarized potential of $-58.6 \pm 0.6 \mathrm{mV}(n=6)$. This indicates a reduced intracellular $\mathrm{Cl}^{-}$resulting from overexpression of KCC2. These results also indicate that overexpression of KCC2 alone can induce functional transport in cultured neurons within the first week in vitro, despite other cellular processes that are typically required to mature to confer functional activity (Kelsch et al., 2001; Khirug et al., 2005). At 10 DIV, incubation with control neurons with $\mathrm{H}_{2} \mathrm{O}_{2}(50 \mu \mathrm{M})$ for up to $9 \mathrm{~h}$ resulted in $\sim 50 \%$ of neurons observed unable to exclude trypan blue. For 
neurons from the same cultures that overexpressed KCC2, the loss of cell viability was markedly reduced, and this was observed at both 3 and $9 \mathrm{~h}$ incubation times. After $9 \mathrm{~h}$ incubation, for example, only $\sim 20 \%$ of neurons were unable to exclude trypan blue (Fig. 6C).

Our next approach to investigating functional consequences of KCC2 tyrosine phosphorylation during oxidative stress was to incubate neurons with both $\mathrm{H}_{2} \mathrm{O}_{2}(50 \mu \mathrm{M})$ and the tyrosine phosphatase inhibitor $\mathrm{Na}_{3} \mathrm{VO}_{4}(100 \mu \mathrm{M})$, resulting in an increased proportion of tyrosinephosphorylated KCC2 (Fig. 4). After $3 \mathrm{~h}$ of $\mathrm{Na}_{3} \mathrm{VO}_{4}$ and $\mathrm{H}_{2} \mathrm{O}_{2}$ incubation, the loss of cell viability was markedly reduced (Fig. $6 C)$. Decrease of the loss of cell viability could also be observed in an incubation with $\mathrm{H}_{2} \mathrm{O}_{2}$ and other possible tyrosine phosphatase blockers, phenylarsine oxide and $\mathrm{Na}_{2} \mathrm{MoO}_{4}$ (supplemental Fig. 4, available at www.jneurosci.org as supplemental material). After more prolonged $\mathrm{Na}_{3} \mathrm{VO}_{4}$ and $\mathrm{H}_{2} \mathrm{O}_{2}$ incubation ( $9 \mathrm{~h}$ ), however, the proportion of neurons unable to exclude trypan blue was not significantly different from that in control neurons. Both these sets of experiments suggest that increasing the relative proportion of tyrosine-phosphorylated KCC2 protects against the loss of cell viability in response to short periods of oxidative stress, whereas increasing KCC2 expression levels can sustain cell viability for prolonged periods of oxidative stress.

\section{Discussion}

Do changes in KCC2 expression levels after neuronal stress alone determine cellular KCC2 activity?

A hyperpolarizing ionotropic GABA receptor response in neurons occurs primarily because of the ability of KCC2 to use the transmembrane $\mathrm{K}^{+}$gradient to extrude $\mathrm{Cl}^{-}$and hence keep $\left[\mathrm{Cl}^{-}\right]_{\mathrm{i}}$ low. Various neuronal traumas can result in a conversion of the GABAergic response to a depolarization. In some instances, such a depolarizing GABA response has been correlated with a decrease in KCC2 expression [axotomy (Nabekura et al., 2002; Toyoda et al., 2003), seizures (Rivera et al., 2002), neuropathic pain (Coull et al., 2003)]. Given the rapid turnover of membrane-bound KCC2 (Rivera et al., 2004), and possible subsequent degradation, these data are compatible with a hypothesis in which KCC2 expression levels may be the principal determinant of changes in cellular KCC2 activity in response to injury. However, there are also some instances of mismatches apparent between altered KCC2 expression levels and functional consequences. In a model of in vivo cortical epilepsy, Jin et al. (2005) indicate an apparent downregulation of KCC2 expression without marked changes in KCC2 activity. Fiumelli et al. (2005) reported a neuronal activity and
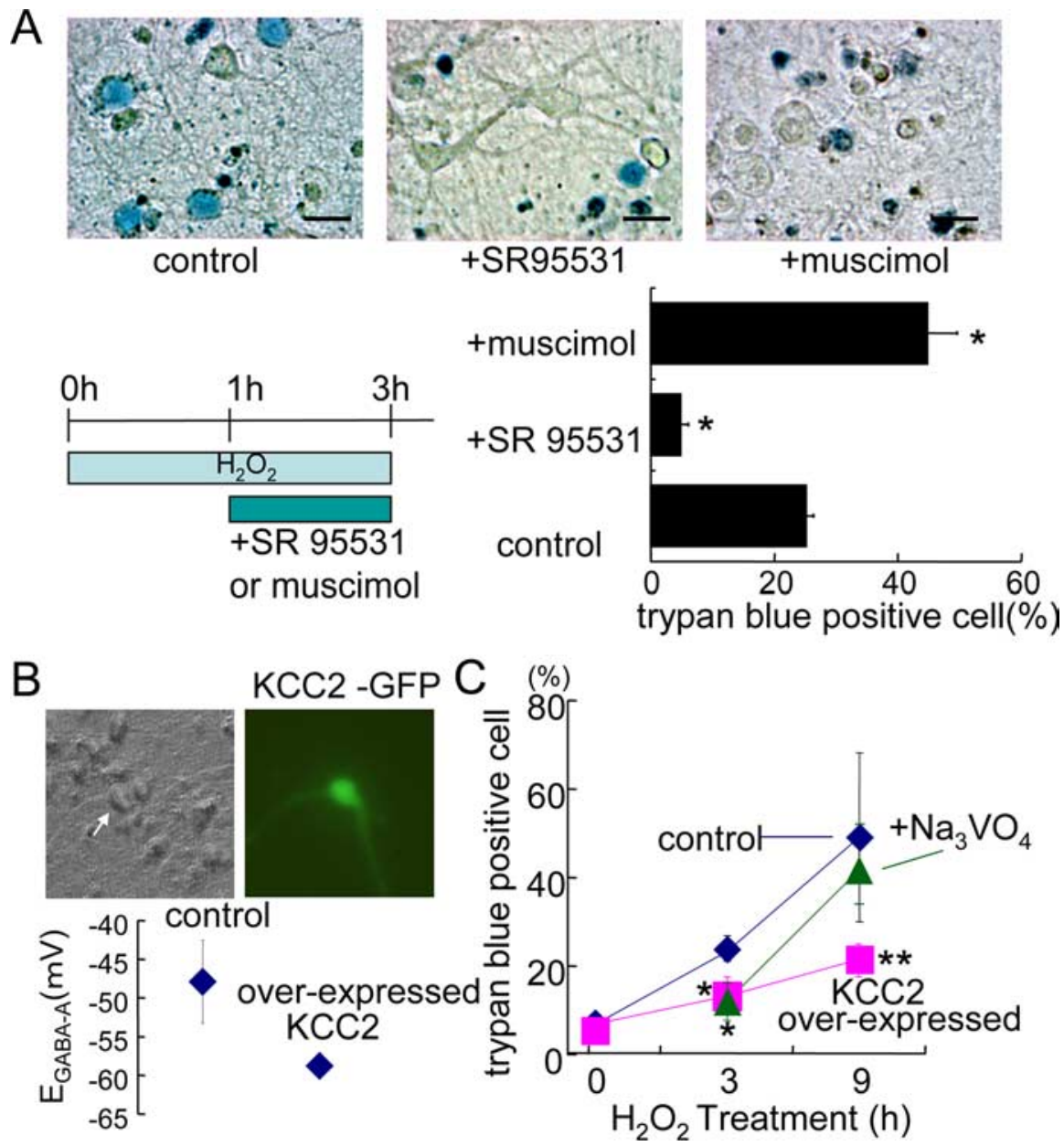

Figure 6. The role of $\mathrm{KCC} 2$ downregulation and $G A B A_{A}$ receptor ligands on the survival of cultured hippocampal neurons during $\mathrm{H}_{2} \mathrm{O}_{2}$ incubation. $A$, Top panels, Examples of cultured hippocampal neurons incubated with $\mathrm{H}_{2} \mathrm{O}_{2}(50 \mu \mathrm{m})$ for $3 \mathrm{~h}$. Cell viability was assayed by trypan blue exclusion with neurons stained blue indicating cell damage and/or death. The left panel shows control neurons ( $\mathrm{H}_{2} \mathrm{O}_{2}$ only). The middle panel shows neurons incubated with $\mathrm{H}_{2} \mathrm{O}_{2}$ and the $\mathrm{GABA}_{\mathrm{A}}$ receptor antagonist SR $95531(30 \mu \mathrm{M})$. The right panel shows neurons incubated with $\mathrm{H}_{2} \mathrm{O}_{2}$ and the $\mathrm{GABA}_{\mathrm{A}}$ receptor agonist muscimol ( $\left.30 \mu \mathrm{M}\right)$. SR 95531 or muscimol with muscimol or SR 95531. The averaged data derives from measurements of over 300 cells, in three different cell cultures. Error fluorescent image of KCC2-GFP-overexpressed neurons (right). The arrow in the left image indicates the neuron expressing GFP, shown in the right image. The bottom graph shows $E_{G A B A}$ in control neurons (without GFP) and in KCC2-overexpressing neurons C, The averaged time course of the loss of cultured hippocampal neuron (10 DIV) viability after 3 and $9 \mathrm{~h} \mathrm{H}_{2} \mathrm{O}_{2}(50 \mu \mathrm{M})$ incubation (control). In neurons overexpressing KCC2 (KCC2 overexpressed; pink squares) identified with GFP, the loss of cell viability was viability at $3 \mathrm{~h}$ was reduced but was back at control levels at $9 \mathrm{~h}$. Error bars indicate SEM. ${ }^{* *} p<0.01,{ }^{*} p<0.05$ compared with the same time point under control conditions.

$\mathrm{Ca}^{2+}$ and PKC (protein kinase C)-dependent downregulation of KCC2 function that occurred too rapidly to be mediated by alterations in KCC2 expression. Furthermore, during in vitro neuronal development of hippocampal neurons, it is clear that KCC2 can be present at early stages but nonfunctional, with activity induced by a broad kinase inhibition or with tyrosine kinase activation (Kelsch et al., 2001; Zhu et al., 2005), although whether these changes in phosphorylation were to KCC2 itself or some accessory protein is not investigated. Our results demonstrate that loss of direct KCC2 tyrosine phosphorylation occurs in response to neuronal stress and that this dephosphorylation correlates to loss of functional KCC2 activity and also precedes changes in KCC2 expression levels. Hence changes in cellular KCC2 ac- 
tivity can occur in response to injury independent of changes in expression levels. The resultant initial increase of $\left[\mathrm{Cl}^{-}\right]_{\mathrm{i}}$ led to a reduced or absent GABA hyperpolarization. During more prolonged neuronal stress, a second phase of $\left[\mathrm{Cl}^{-}\right]_{\mathrm{i}}$ increase was apparent that was associated with a conversion of the GABA response to a depolarization and a reduced expression of KCC2 protein. Hence we would propose that injury results in two phases of reduced KCC2 activity: an initial downregulation attributable to loss of tyrosine phosphorylation and a second phase correlated with loss of KCC2 protein levels.

Although KCC2 is primarily responsible for maintaining low $\left[\mathrm{Cl}^{-}\right]_{\mathrm{i}}$ and hyperpolarizing GABA responses in adult neurons (Kakazu et al., 1999), the cation-chloride cotransporter NKCC1 also contributes to neuronal $\mathrm{Cl}^{-}$homeostasis (Okabe et al., 2003). Our present study has not addressed whether the activity of this transporter also changes with neuronal stress. Pond et al. (2006) have reported that the activity of NKCC1 in hippocampal neurons increases in response to in vitro ischemia, via an increased serine/threonine phosphorylation. An increased NKCC1 activity would result in additional increases in $\left[\mathrm{Cl}^{-}\right]_{\mathrm{i}}$, exacerbating the consequences of KCC2 functional downregulation.

\section{Mechanism linking loss of tyrosine phosphorylation to reduced cellular KCC2 activity}

The correlation between dephosphorylated KCC2 and the loss of surface expression of KCC2 is consistent with the functional downregulation being attributable to alterations in membrane trafficking of the KCC2 protein, either an increase in internalization/endocytosis or a decrease in insertion/exocytosis. Little is known about the mechanisms underlying these processes in regards to cation-chloride transporters, despite the recent suggestion for the related NKCC2 protein, that dynamic alterations in surface expression may mediate hormone-evoked changes in kidney salt transport (Meade et al., 2003), despite the wealth of studies on acute regulation of surface expression of other membrane proteins (Kittler and Moss, 2003; Le Roy and Wrana, 2005). Our studies show that $\mathrm{Na}_{3} \mathrm{VO}_{4}$ prevented the loss of surface KCC2 expression in response to oxidative stress, suggesting that tyrosine dephosphorylation precedes loss of KCC2 surface expression. Rivera et al. (2004) reported that $0 \mathrm{Mg}^{2+}$-induced epileptic activity increased the turnover rate of biotinylated surface-expressed KCC2. It is interesting to speculate that the increased internalized KCC2 was attributable to a loss of tyrosine phosphorylation, whereas a fraction (20\%), seemingly more membrane stable, remained phosphorylated and functional. Additional clarification of the underlying mechanisms responsible for membrane trafficking, and whether this involves KCC2 tyrosine dephosphorylation, is an important question for future studies.

Our data suggest that stress or injury can induce an increase in the KCC2 tyrosine phosphorylation/dephosphorylation rate, with an overall reduction in the tyrosine-phosphorylated proportion of KCC2 and a resulting rapid loss of function associated with reductions in membrane surface expression. Clearly, other signaling mechanisms exist to acutely modulate KCC2 function in response to different stimuli. In regard to tyrosine phosphorylation, activation of the receptor tyrosine kinase TrkB, in response to $0 \mathrm{Mg}^{2+}$ incubation, can result in functional KCC2 downregulation and reduced KCC2 cellular expression, in a process involving both phospholipase $\mathrm{C} \gamma$ and the src homology 2 domain containing transforming protein (Rivera et al., 2004). Conversely, exogenous activation of the cytoplasmic tyrosine kinase, src, has been shown to activate KCC2 in cultured neurons
(Kelsch et al., 2001). In response to sustained postsynaptic spike activity, KCC2 function was rapidly downregulated in cultured hippocampal neurons, via a $\mathrm{Ca}^{2+}$-dependent signaling mechanism that did not involve tyrosine kinases or serine/threonine phosphatases, but rather involved activation of protein kinase $\mathrm{C}$ (Fiumelli et al., 2005). However, in none of these previous studies was the phosphorylation state of KCC2 directly examined, so it remains unclear whether the effects were attributable to changes in the phosphorylation of KCC2 itself or of some modulatory protein.

\section{Functional significance of KCC2 downregulation}

Seizure activity, oxidative stress, axotomy, nerve injury, and arthritis all result in decreases in KCC2 expression and function, and a conversion of GABA-mediated responses toward depolarization. Whether this process contributes to the pathological symptoms and/or neuronal damage, or is an adaptive response to promote recovery is not totally clear and may depend on the type of insult. The conversion of GABAergic responses to depolarizing has been shown to be present in a range of in vitro and in vivo seizure models and in human epileptics (Cohen et al., 2002; Khalilov et al., 2003; Rivera et al., 2004; Jin et al., 2005) (for review, see Cossart et al., 2005), and KCC2 downregulation may be important in the genesis and maintenance of seizure activity. Consistently, neonatal neurons have both a reduced KCC2 expression and show increased seizure susceptibility, although the correlation does not precisely match (Khazipov et al., 2004). BDNF-induced downregulation of $\mathrm{KCC} 2$ can be correlated to a model in which BDNF generates seizures in response to a variety of causes (Binder et al., 2001; Rivera et al., 2002). In addition, BDNF decreases the IPSCs in amplitude in the hippocampal excitatory neurons (Mizoguchi et al., 2003), introduced by the depolarizing shift of IPSC reversal potential (Wardle and Poo, 2003 ) as well as by the internalization of $\mathrm{GABA}_{\mathrm{A}}$ receptors (Kanematsu et al., 2003). However, elevations in extracellular $\mathrm{K}^{+}$that are likely to occur with increased neuronal activity, may reverse the direction of transport for $\mathrm{KCC} 2$, so that it results in $\mathrm{Cl}^{-}$influx (Payne, 1997; Kakazu et al., 2000). Furthermore, KCC and related transporters may contribute to volume changes and cell swelling that can exacerbate seizures (Schwartzkroin et al., 1998; Haglund and Hochman, 2005). In these situations, a reduction in KCC2 activity would actually reduce GABAergic depolarization and neuronal activity, and it remains conceivable that functional downregulation may be an adaptive and neuroprotective response to seizure activity.

In our simple model of in vitro oxidative stress, overexpression of $\mathrm{KCC} 2$, and the subsequent maintenance of $\left[\mathrm{Cl}^{-}\right]_{\mathrm{i}}$ homeostasis, was neuroprotective. Similarly, inhibition of phosphatase activity in these cells, which may be expected to reduce the downregulation of KCC2 tyrosine phosphorylation and function (among other things), also enhanced neuronal survival, again suggesting that functional downregulation of KCC2 may contribute to neuronal damage. Importantly, phosphatase inhibition did not affect neuronal viability during prolonged oxidative stress, corresponding to the second phase of KCC2 downregulation attributable to loss of KCC2 expression. Although oxidative stress may cause loss of neuronal viability for multiple reasons, part of this response involved, at least in our experimental conditions, activation of $\mathrm{GABA}_{\mathrm{A}}$ receptors. Whittemore et al. (1995) reported, for cultured cortical neurons, that $\mathrm{H}_{2} \mathrm{O}_{2}$ can result in elevations of intracellular $\mathrm{Ca}^{2+}$. Hence one simple possibility is that, by preventing KCC2 functional downregulation and GABA- 
induced depolarization, there may be reduced excitotoxic $\mathrm{Ca}^{2+}$ influx (Sattler and Tymianski, 2000).

Additional insights into the role of KCC in different types of neuronal stress require careful consideration of the time course of functional changes in KCC2, manipulation of these changes, and monitoring the effects of these manipulations on neuronal damage and/or recovery. Understanding the mechanisms underlying functional changes in KCC2 in response to different neuronal stress may result in novel strategies for reducing neuronal damage and/or promoting neuronal recovery in different pathological states.

\section{References}

Adragna NC, Fulvio MD, Lauf PK (2004) Regulation of K-Cl cotransport: from function to genes. J Membr Biol 201:109-137.

Binder DK, Croll SD, Gall CM, Scharfman HE (2001) BDNF and epilepsy: too much of a good thing? Trends Neurosci 24:47-53.

Cohen I, Navarro V, Clemenceau S, Baulac M, Miles R (2002) On the origin of interictal activity in human temporal lobe epilepsy in vitro. Science 298:1418-1421

Cossart R, Bernard C, Ben-Ari Y (2005) Multiple facets of GABAergic neurons and synapses: multiple fates of GABA signalling in epilepsies. Trends Neurosci 28:108-115.

Coull JA, Boudreau D, Bachand K, Prescott SA, Nault F, Sik A, De Koninck P, De Koninck Y (2003) Trans-synaptic shift in anion gradient in spinal lamina I neurons as a mechanism of neuropathic pain. Nature 424:938-942.

Delpire E (2000) Cation-chloride cotransporters in neuronal communication. News Physiol Sci 15:309-312.

Fiumelli H, Cancedda L, Poo MM (2005) Modulation of GABAergic transmission by activity via postsynaptic $\mathrm{Ca}^{2+}$-dependent regulation of KCC2 function. Neuron 48:773-786.

Haglund MM, Hochman DW (2005) Furosemide and mannitol suppression of epileptic activity in the human brain. J Neurophysiol 94:907-918.

Jin X, Huguenard JR, Prince DA (2005) Impaired $\mathrm{Cl}^{-}$extrusion in layer V pyramidal neurons of chronically injured epileptogenic neocortex. J Neurophysiol 93:2117-2126.

Kaila K (1994) Ionic basis of $\mathrm{GABA}_{\mathrm{A}}$ receptor channel function in the nervous system. Prog Neurobiol 42:489-537.

Kakazu Y, Akaike N, Komiyama S, Nabekura J (1999) Regulation of intracellular chloride by cotransporters in developing lateral superior olive neurons. J Neurosci 19:2843-2851.

Kakazu Y, Uchida S, Nakagawa T, Akaike N, Nabekura J (2000) Reversibility and cation selectivity of the $\mathrm{K}^{+}-\mathrm{Cl}^{-}$cotransport in rat central neurons. J Neurophysiol 84:281-288.

Kanematsu T, Yasunaga A, Mizoguchi Y, Kuratani A, Kittler JT, Jovanovic JN, Takenaka K, Nakayama KI, Fukami K, Takenawa T, Moss SJ, Nabekura J, Hirata M (2006) Modulation of $\mathrm{GABA}_{\mathrm{A}}$ receptor phosphorylation and membrane trafficking by phospholipase C-related inactive protein/protein phosphatase 1 and $2 \mathrm{~A}$ signaling complex underlying brain-derived neurotrophic factor-dependent regulation of GABAergic inhibition. J Biol Chem 281:22180-22189.

Kelsch W, Hormuzdi S, Straube E, Lewen A, Monyer H, Misgeld U (2001) Insulin-like growth factor 1 and a cytosolic tyrosine kinase activate chloride outward transport during maturation of hippocampal neurons. J Neurosci 21:8339-8347.

Khalilov I, Holmes GL, Ben-Ari Y (2003) In vitro formation of a secondary epileptogenic mirror focus by interhippocampal propagation of seizures. Nat Neurosci 6:1079-1085.

Khazipov R, Khalilov I, Tyzio R, Morozova E, Ben-Ari Y, Holmes GL (2004) Developmental changes in GABAergic actions and seizure susceptibility in the rat hippocampus. Eur J Neurosci 19:590-600.

Khirug S, Huttu K, Ludwig A, Smirnov S, Voipio J, Rivera C, Kaila K, Khiroug L (2005) Distinct properties of functional KCC2 expression in immature mouse hippocampal neurons in culture and in acute slices. Eur J Neurosci 21:899-904.

Kittler JT, Moss SJ (2003) Modulation of $\mathrm{GABA}_{\mathrm{A}}$ receptor activity by phosphorylation and receptor trafficking: implications for the efficacy of synaptic inhibition. Curr Opin Neurobiol 13:341-347.
Le Roy C, Wrana JL (2005) Clathrin- and non-clathrin-mediated endocytic regulation of cell signalling. Nat Rev Mol Cell Biol 6:112-126.

Meade P, Hoover RS, Plata C, Vazquez N, Bobadilla NA, Gamba G, Hebert SC (2003) cAMP-dependent activation of the renal-specific $\mathrm{Na}^{+}-\mathrm{K}^{+}-2 \mathrm{Cl}^{-}$ cotransporter is mediated by regulation of cotransporter trafficking. Am J Physiol 284:F1145-F1154.

Mizoguchi Y, Ishibashi H, Nabekura J (2003) The action of BDNF on $\mathrm{GABA}_{\mathrm{A}}$ currents changes from potentiating to suppressing during maturation of rat hippocampal CA1 pyramidal neurons. J Physiol (Lond) 548:703-709.

Nabekura J, Omura T, Akaike N (1996) Alpha 2 adrenoceptor potentiates glycine receptor-mediated taurine response through protein kinase $\mathrm{A}$ in rat substantia nigra neurons. J Neurophysiol 76:2447-2454.

Nabekura J, Ueno T, Okabe A, Furuta A, Iwaki T, Shimizu-Okabe C, Fukuda A, Akaike N (2002) Reduction of KCC2 expression and $\mathrm{GABA}_{A}$ receptor-mediated excitation after in vivo axonal injury. J Neurosci 22:4412-4417.

Okabe A, Yokokura M, Toyada H, Shimizu-Okabe C, Ohno K, Sato K, Fukuda A (2003) Changes in chloride homeostasis-regulating gene expressions in the rat hippocampus following amygdala kindling. Brain Res 990:221-226.

Payne JA (1997) Functional characterization of the neuronal-specific K-Cl cotransporter: implications for $\left[\mathrm{K}^{+}\right]_{\mathrm{o}}$ regulation. Am J Physiol 273:C1516-C1525.

Payne JA, Rivera C, Voipio J, Kaika K (2003) Cation-chloride cotransporters in neuronal communication, development and trauma. Trends Neurosci 26:199-206.

Pond BB, Berglund K, Kuner T, Feng G, Augustine GJ, Schwartz-Bloom RD (2006) The chloride transporter $\mathrm{Na}^{+}-\mathrm{K}^{+}-\mathrm{Cl}^{-}$cotransporter isoform-1 contributes to intracellular chloride increases after in vitro ischemia. J Neurosci 26:1396-1406.

Rivera C, Voipio J, Payne JA, Ruusuvuori E, Lahtinen H, Lamsa K, Pirvola U, Saarma M, Kaila K (1999) The $\mathrm{K}^{+} / \mathrm{Cl}^{-}$co-transporter KCC2 renders GABA hyperpolarizing during neuronal maturation. Nature 397:251-255.

Rivera C, Li H, Thomas-Crusells J, Lahtinen H, Viitanen T, Nanobashvili A, Kokaia Z, Airaksinen MS, Voipio J, Kaila K, Saarma M (2002) BDNFinduced TrkB activation down-regulates the $\mathrm{K}^{+}-\mathrm{Cl}^{-}$cotransporter KCC2 and impairs neuronal $\mathrm{Cl}^{-}$extrusion. J Cell Biol 159:747-752.

Rivera C, Voipio J, Thomas-Crusells J, Li H, Emri Z, Sipila S, Payne JA, Minichiello L, Saarma M, Kaila K (2004) Mechanism of activitydependent downregulation of the neuron-specific $\mathrm{K}-\mathrm{Cl}$ cotransporter KCC2. J Neurosci 24:4683-4691.

Sattler R, Tymianski M (2000) Molecular mechanisms of calciumdependent excitotoxicity. J Mol Med 78:3-13.

Schwartzkroin PA, Baraban SC, Hochman DW (1998) Osmolarity, ionic flux, and changes in brain excitability. Epilepsy Res 32:275-285.

Swarup G, Cohen S, Garbers DL (1982) Inhibition of membrane phosphotyrosyl-protein phosphatase activity by vanadate. Biochem Biophys Res Commun 107:1104-1109.

Toyoda H, Ohno K, Yamada J, Ikeda M, Okabe A, Sato K, Hashimoto K, Fukuda A (2003) Induction of NMDA and GABAA receptor-mediated $\mathrm{Ca}^{2+}$ oscillations with KCC2 mRNA downregulation in injured facial motoneurons. J Neurophysiol 89:1353-1362.

Ueno T, Okabe A, Akaike N, Fukuda A, Nabekura J (2002) Diversity of neuron-specific $\mathrm{K}^{+}-\mathrm{Cl}^{-}$cotransporter expression and inhibitory postsynaptic potential depression in rat motoneurons. J Biol Chem 277:4945-4950.

Wardle RA, Poo MM (2003) Brain-derived neurotrophic factor modulation of GABAergic synapses by postsynaptic regulation of chloride transport. J Neurosci 23:8722-8732.

Whittemore ER, Loo DT, Watt JA, Cotman CW (1995) A detailed analysis of hydrogen peroxide-induced cell death in primary neuronal culture. Neuroscience 67:921-932.

Williams JR, Sharp JW, Kumari VG, Wilson M, Payne JA (1999) The neuron-specific $\mathrm{K}-\mathrm{Cl}$ cotransporter, KCC2. Antibody development and initial characterization of the protein. J Biol Chem 274:12656-12664.

Zhu L, Lovinger D, Delpire E (2005) Cortical neurons lacking KCC2 expression show impaired regulation of intracellular chloride. J Neurophysiol 93:1557-1568. 